\title{
Erratum to: The Palgrave Handbook of Masculinity and Political Culture in Europe
}

\author{
Christopher Fletcher, Sean Brady, Rachel E. Moss and Lucy Riall
}

\section{Erratum to:}

C. Fletcher et al. (eds.), The Palgrave Handbook of Masculinity and Political Culture in Europe, https://doi.org/10.1057/978-1-137-58538-7

In the original version of the book, the following corrections have been incorporated:

The chapter 'A Man's Sphere? British Politics in the Eighteenth and Nineteenth Centuries' was originally published as (C) Palgrave Macmillan but has now been made available as (C) The Author and open access under a CC BY 4.0 license.

In 'Antonio Canova's Statue of King Ferdinand IV and the Gendering of Neapolitan Sovereignty',

Acknowledgements have been included as an article note in the opening page of the chapter.

The cropping of Figure 4 has been amended.

A mail symbol next to author's name on the first page of the chapter has been removed.

In the Frontmatter,

On p. viii, additions have been made to the acknowledgments.

The erratum book has been updated with these changes.

The updated online version of this book can be found at https://doi.org/10.1057/978-1-137-58538-7_12 https://doi.org/10.1057/978-1-137-58538-7_14 https://doi.org/10.1057/978-1-137-58538-7 